\title{
KESINTASAN PASIEN LEUKEMIA LIMFOBLASTIK AKUT PADA ANAK DI RSUP.DR.WAHIDIN SUDIROHUSODO MAKASSAR
}

\section{SURVIVAL OF PATIENTS ACUTE LYMPHOBLASTIC LEUKEMIA IN CHILDREN AT DR.WAHIDIN SUDIROHUSODO GENERAL HOSPITAL MAKASSAR}

\author{
Rezki Elisafitri ${ }^{1}$, A. Arsunan Arsin ${ }^{1}$, Atjo Wahyu ${ }^{2}$ \\ ${ }^{1}$ Bagian Epidemiologi, Fakultas Kesehatan Masyarakat, Universitas Hasanuddin \\ ${ }^{2}$ Bagian Kesehatan dan Keselamatan Kerja, Fakultas Kesehatan Masyarakat, Universitas \\ Hasanuddin
}

\begin{abstract}
Alamat Korespondensi: Rezki Elisafitri, S.KM, Fakultas Kesehatan Masyarakat
Universitas Hasanuddin, Makassar, 90245, HP: +6285342057122,

Email: rezkielisafitrisahudi@gmail.com
\end{abstract}

\begin{abstract}
ABSTRAK
Leukemia Limfoblastik Akut (LLA) merupakan salah satu keganasan hematologi yang paling banyak diderita oleh anak-anak. Tolak ukur keberhasilan pengobatan pada pasien leukemia dapat dilihat berdasarkan angka kesintasan. Penelitian ini bertujuan mengetahui proporsi kesintasan pasien LLA pada anak di RSUP Dr.Wahidin Sudirohusodo dan faktor prognosis yang mempengaruhinya. Penelitian ini menggunakan desain studi observasional analitik dengan rancangan kohort retrospektif. Sampel pada penelitian ini adalah pasien LLA yang didiagnosis tahun 2014-2017 di RSUP Dr.Wahidin Sudirohusodo. Sebanyak 109 pasien dipilih secara simple random sampling. Data penelitian dikumpulkan dengan melakukan penelusuran rekam medik pasien. Data dianalisis menggunakan analisis Kaplan-Meier dan Cox Regression. Hasil penelitian menunjukkan bahwa proporsi kesintasan 48 bulan pasien LLA pada anak di RSUP Dr. Wahidin Sudirohusodo Makassar sebesar $26 \%$. Faktor prognosis yang berhubungan secara statistik dengan kesintasan pasien LLA adalah status gizi $(p=0,028)$, sedangkan umur dan jenis kelamin tidak berhubungan dengan kesintasan pasien LLA $(p>0,05)$. Berdasarkan analisis multivariat dengan cox regression model interaksi, faktor prognosis yang paling berpengaruh terhadap kesintasan pasien LLA adalah status gizi $(p=0,040 ; \mathrm{HR}=1,739$ CI 95\% 1,024-2,952). Pasien LLA dengan status gizi abnormal memiliki risiko kematian 1,739 kali lebih tinggi dibandingkan pasien LLA dengan status gizi normal.
\end{abstract}

Kata Kunci: Leukemia Limfoblastik Akut, Kesintasan, Anak, Faktor Prognosis

\section{ABSTRACT}

Acute Lymphoblastic Leukemia (ALL) is one of the most common hematological malignancies in children. Measuring the success of treatment in leukemia patients can be seen based on survival rates. This study aims to determine the proportion of survival of ALL patients in children at Dr.Wahidin Sudirohusodo and the factors that influence the prognosis. This study uses the design of analytic observational studies with a retrospective cohort design. The sample in this study were ALL patients diagnosed in 2014-2017 at Dr.Wahidin Sudirohusodo Hospital. A total of 109 patients were selected by simple random sampling. The data were collected by conducting patient medical record. Data were analyzed using Kaplan-Meier analysis and Cox Regression. The results showed that the proportion of survival of 48 months for ALL patients in children at Dr. Wahidin Sudirohusodo Makassar is $26 \%$. The prognostic factors associated statistically with survival of ALL patients were nutritional status $(p=0,028)$, whereas age and sex did not correlate with survival of ALL patients $(p>0,05)$. Based on multivariate analysis with cox regression of interaction model, the most influential prognosis factor on survival of ALL patients was nutritional status ( $p=0,040, H R=1,739$ CI 95\% 1,024-2,952). ALL patients with abnormal nutritional status had a risk of death 1,739 times higher than ALL patients with normal nutritional status.

Keywords: Acute Lymphoblastic Leukemia, survival, child, prognosis factors 


\section{PENDAHULUAN}

Penyakit kanker merupakan salah satu penyebab kematian utama di tingkat global, termasuk leukemia. Jenis kanker yang paling banyak diderita oleh anak-anak adalah leukemia akut, mencapai 97\% dari semua jenis leukemia (Permono, 2012). Leukemia Limfoblastik Akut (LLA) merupakan salah satu keganasan hematologi yang paling sering ditemui pada anak, dengan insiden tiap tahun yang cenderung meningkat. Data Facts 20162017 oleh Leukemia and Lymphoma Society (LLS) menunjukkan bahwa pada tahun 2009 hingga 2013, LLA menyumbang $74,5 \%$ insiden leukemia pada anak-anak yang berumur kurang dari 20 tahun (LLS, 2018).

Prevalensi kanker pada anak umur 0-14 tahun berdasarkan data Riset Kesehatan Dasar (Riskesdas) tahun 2013 sebesar 16291 kasus. Leukemia merupakan jenis kanker yang paling banyak diderita oleh anak-anak di Indonesia (Kemenkes, 2016). Berdasarkan data rekam medik RSUP Dr.Wahidin Sudirohusodo Makassar, prevalensi LLA di Provinsi Sulawesi Selatan selama tiga tahun terakhir cenderung meningkat dan merupakan penyakit dengan jumlah kasus terbanyak pada bagian perawatan anak. Pada tahun 2015 terdapat 60 kasus, meningkat pada tahun 2016 menjadi 63 kasus, dan pada tahun 2017 meningkat menjadi 67 kasus (Rekam Medik RSUP
Dr.Wahidin Sudirohusodo, 2018).

Angka kesintasan (survival rate) merupakan tolak ukur untuk menilai keberhasilan pengobatan suatu penyakit. Faktor prognosis leukemia menjadi tolak ukur dokter dalam menentukan pengobatan yang akan diberikan kepada pasien leukemia. Prognosis yang buruk akan mempengaruhi kesintasan seseorang terhadap suatu penyakit. Beberapa faktor prognostik LLA telah diteliti oleh Wirawan et al. (2003) dan Permono (2012), antara lain umur, jenis kelamin, dan status gizi.

Umur saat diagnosis adalah faktor prognosis kunci pada anak yang menderita LLA. Penelitian yang dilakukan oleh Hossain et al. (2014) di Amerika Serikat dan Permatasari et al. (2009) di Indonesia melalui desain studi cohort retrospektif menunjukkan bahwa umur berpengaruh secara signifikan terhadap probabilitas kesintasan anak dengan LLA. Secara umum, penderita LLA yang berumur muda cenderung memiliki prognosis yang lebih baik daripada penderita yang berumur lebih tua.

Selain umur, faktor prognosis LLA yang tidak bisa diubah adalah jenis kelamin. Menurut Wirawan et al. (2003), pasien LLA yang berjenis kelamin lakilaki memiliki prognosis yang lebih buruk dibandingkan jenis kelamin perempuan. Penelitian yang dilakukan oleh Erdmann et al. (2014) di Jerman dan Simanjorang et al. 
(2013) di Jakarta menemukan bahwa jenis kelamin berpengaruh secara signifikan terhadap probabilitas kesintasan anak dengan LLA. Survival rate meningkat pada pasien LLA yang berjenis kelamin perempuan.

Status gizi pasien saat pertama kali didiagnosis LLA akan berpengaruh terhadap hasil akhir pengobatan. Gelelete et al. (2011) dalam penelitiannya menemukan bahwa obesitas mempengaruhi kesintasan anak yang menderita LLA. Pasien LLA yang mengalami obesitas memiliki survival rate yang lebih buruk dibandingkan pasien nonobesitas. Penelitian Hoed et al. (2015) menyimpulkan bahwa kekurangan berat badan pada saat diagnosis LLA merupakan faktor risiko terjadinya kekambuhan dan penurunan indeks massa tubuh (IMT) selama pengobatan terkait dengan penurunan ketahanan hidup.

Beberapa penelitian telah dilakukan untuk membuktikan hubungan antara faktor prognosis seperti umur, jenis kelamin, dan status gizi dengan angka kesintasan anak dengan LLA. Namun, beberapa hasil penelitian yang diperoleh masih tidak konsisten. Dengan menelaah survival rate penderita leukemia, dapat membantu dalam hal pengembangan informasi terkait leukemia untuk penanggulangan di masa yang akan datang. Penelitian ini bertujuan untuk mengetahui angka kesintasan pasien LLA pada anak di
RSUP Dr. Wahidin Sudirohusodo Makassar dan faktor prognosis yang mempengaruhinya.

\section{BAHAN DAN METODE}

\section{Lokasi dan Desain Penelitian}

Penelitian ini dilakukan di RSUP Dr. Wahidin Sudirohusodo Makassar, Provinsi Sulawesi Selatan. Jenis penelitian yang digunakan adalah observasional analitik dengan rancangan kohort retrospektif.

\section{Populasi dan Sampel}

Populasi pada penelitian ini adalah semua pasien LLA pada anak yang didiagnosis dan mendapatkan pengobatan di RSUP Dr. Wahidin Sudirohusodo Makassar tahun 2014-2017. Sampel sebanyak 109 orang dipilih secara simple random sampling. Kriteria sampel dalam penelitian ini adalah anak yang berumur 0-18 tahun saat pertama kali didiagnosis LLA serta memiliki catatan medik yang lengkap dan memenuhi kriteria variabel yang diteliti.

\section{Pengumpulan Data}

Pengumpulan data dalam penelitian ini dilakukan dengan melalui penelusuran rekam medik pasien LLA. Instrumen yang digunakan berupa lembar observasi. Data yang diambil pada rekam medik pasien disesuaikan dengan kebutuhan penelitian mencakup data jenis kelamin, tanggal lahir, umur diagnosa, alamat atau asal 
daerah, nomor telepon, jenis pembiayaan, status gizi, karakteristik LLA, pengelompokan risiko LLA, hasil laboratorium (jumlah leukosit dan jumlah trombosit), tanggal kunjungan pertama dan tanggal keluar atau tanggal kunjungan terakhir serta status akhir pasien (hidup atau meninggal). Selain penelusuran rekam medik, peneliti juga melakukan penelusuran melalui media komunikasi telepon untuk menanyakan status pasien kepada orang tua atau keluarga pasien. Jika nomor telepon orang tua atau keluarga pasien tidak bisa dihubungi, maka penentuan status pasien dilakukan berdasarkan kondisi terakhir pasien saat kontrol terakhir di rumah sakit sesuai yang tercatat pada rekam medik. Jika pasien keluar dalam kondisi baik, maka pasien dikategorikan sensor, sedangkan jika pasien keluar dalam kondisi buruk maka pasien dikategorikan event.

\section{Analisis Data}

Analisis data dilakukan menggunakan sistem komputerisasi program SPSS (Statistical Package and Social Siences). Analisis univariat dilakukan untuk menggambarkan distribusi karakteristik pasien dan variabel penelitian. Analisis bivariat dilakukan untuk mengetahui perbedaan angka kesintasan pasien LLA berdasarkan faktor prognosis (umur, jenis kelamin, dan status gizi) menggunakan metode Kaplan-Meier (kemaknaan hubungan dinilai berdasarkan uji log-rank). Analisis multivariat dilakukan untuk mengetahui variabel yang paling berpengaruh terhadap kesintasan pasien LLA menggunakan uji Cox Regression. Analisis cox regression time independent untuk variabel yang memenuhi asumsi proportional hazard $(\mathrm{PH})$, sedangkan variabel yang tidak memenuhi asumsi PH menggunakan cox regression model interaksi.

\section{HASIL PENELITIAN}

\section{Analisis Univariat}

Tabel 1 menyajikan karakteristik pasien yang menjadi sampel dalam penelitian ini. Dari 109 pasien LLA, lebih banyak pasien yang mengalami event $(63,3 \%)$ dibandingkan sensor. Sebagian besar pasien LLA menderita LLA jenis L1 (95,4\%). Berdasarkan pengelompokan risiko LLA menurut National Cancer Institute (NCI), lebih dari setengah pasien LLA $(54,1 \%)$ adalah kategori High Risk. Adapun proporsi kumulatif kesintasan pasien LLA pada anak yang mencapai 4 tahun (48 bulan) sebesar 26\% (Gambar 1). 


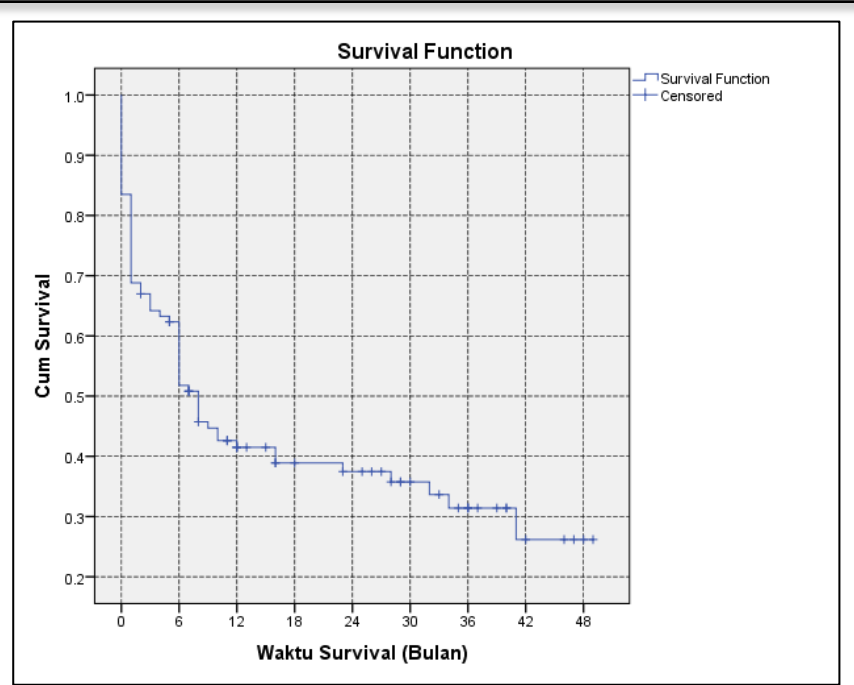

Sumber: Data Sekunder yang Telah Diolah, 2018

\section{Gambar 1. Kesintasan Pasien LLA}

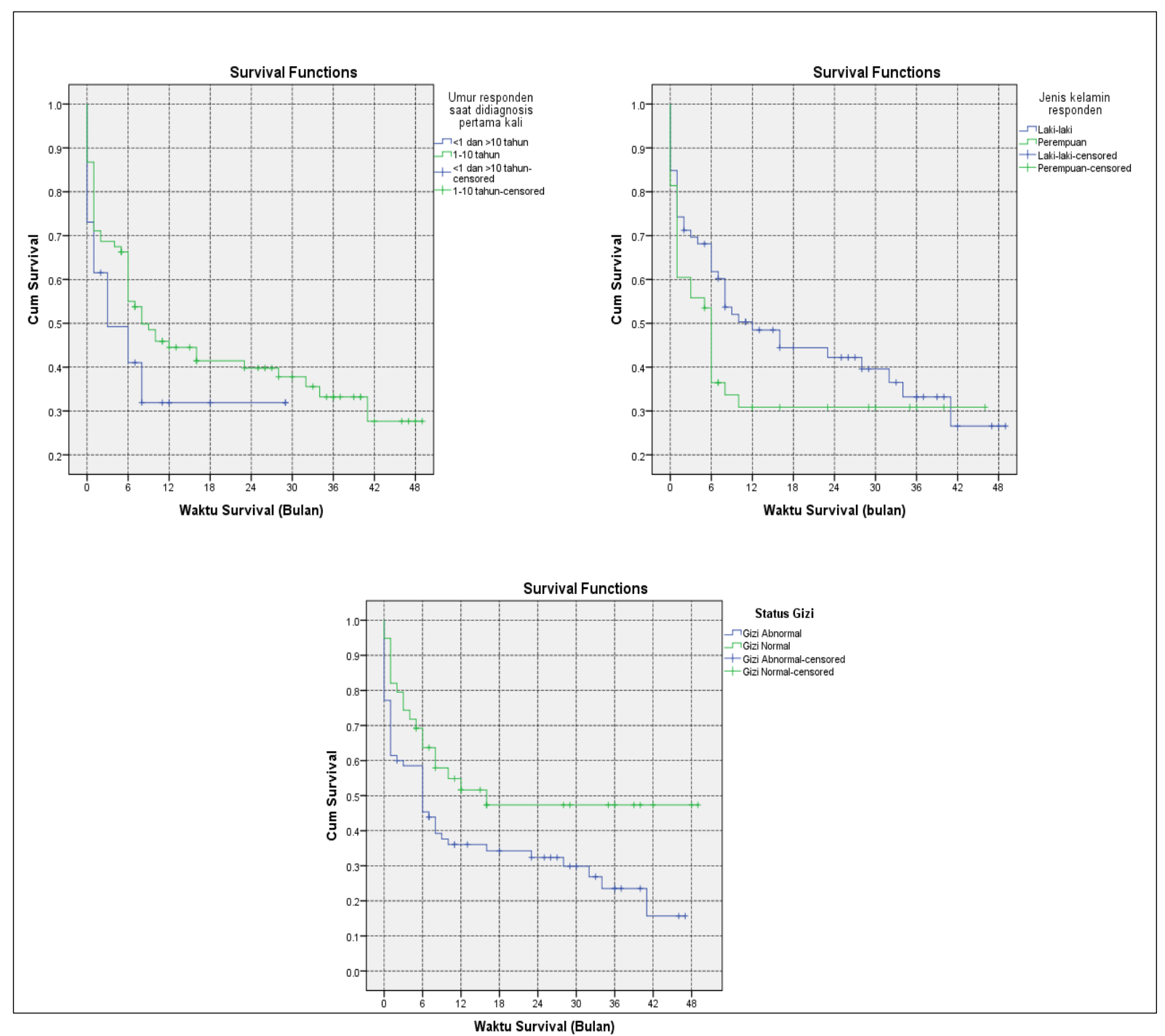

Sumber: Data Sekunder yang Telah Diolah, 2018

Gambar 2. Kesintasan Pasien LLA Berdasarkan Umur, Jenis Kelamin, dan Status Gizi, dengan Metode Kaplan Meier 


\section{Analisis Bivariat}

Sebagian besar pasien LLA berada pada kelompok umur 1-10 tahun (83 orang). Pasien LLA yang mengalami event terbanyak pada kategori umur $<1$ dan $>10$ tahun (65,4\%). Dari 109 pasien LLA, terdapat 66 orang pasien berjenis kelamin laki-laki. Pasien LLA yang mengalami event lebih banyak pada pasien yang berjenis kelamin perempuan $(67,4 \%)$. Berdasarkan status gizi, terdapat 70 orang pasien yang berstatus gizi abnormal. Pasien LLA yang mengalami event lebih banyak pada pasien LLA dengan status gizi abnormal (71,4\%) (Tabel 2).

Survival rate 48 bulan pasien LLA berdasarkan umur yaitu kelompok umur $<1$ dan $>10$ tahun sebesar $31 \%$ dan kelompok umur 1-10 tahun sebesar 27\%. Survival rate 48 bulan pasien LLA berdasarkan jenis kelamin yaitu laki-laki sebesar 26\% dan perempuan sebesar 31\%. Kurva kesintasan pasien LLA berdasarkan umur dan jenis kelamin saling berpotongan. Hal ini menunjukkan asumsi Proportional
Hazard $(\mathrm{PH})$ tidak terpenuhi, dengan nilai $p$ (log rank) $>0,05$. Artinya, tidak ada hubungan yang signifikan antara umur dan jenis kelamin dengan kesintasan pasien LLA. Sedangkan survival rate 48 bulan pasien LLA berdasarkan status gizi yaitu gizi abnormal sebesar 16\% dan gizi normal sebesar 46\%. Kurva kesintasan pasien LLA berdasarkan status gizi tidak saling berpotongan (memenuhi asumsi $\mathrm{PH}$ ), dengan nilai $p(\log$ rank $)=0,028$. Artinya, ada hubungan yang signifikan antara status gizi dengan kesintasan pasien LLA (Gambar 2).

\section{Analisis Multivariat}

Status gizi merupakan variabel yang memiliki pengaruh paling dominan terhadap kesintasan pasien LLA, dengan nilai $p=0,040$ dan $\mathrm{HR}=1,739$ CI $95 \%$ 1,024-2,952). Artinya, setiap saat pasien LLA yang berstatus gizi abnormal 1,739 kali kemungkinannya untuk meninggal dibandingkan dengan pasien LLA yang berstatus gizi normal (Tabel 3).

Tabel 1. Distribusi Karakteristik Pasien

\begin{tabular}{|c|c|c|}
\hline \multirow{2}{*}{ Karakteristik Pasien } & \multicolumn{2}{|c|}{ Frekuensi } \\
\hline & $\mathbf{n}$ & $\%$ \\
\hline \multicolumn{3}{|l|}{ Status Survival } \\
\hline Event & 69 & 63,3 \\
\hline Sensor & 40 & 36,7 \\
\hline \multicolumn{3}{|l|}{ Klasifikasi Morfologik LLA } \\
\hline L1 & 104 & 95,4 \\
\hline $\mathrm{L} 2$ & 5 & 4,6 \\
\hline \multicolumn{3}{|l|}{ Pengelompokan Risiko LLA } \\
\hline High risk & 59 & 54,1 \\
\hline Standart risk & 50 & 45,9 \\
\hline Total & 109 & 100 \\
\hline
\end{tabular}

Sumber : Data Sekunder yang Telah Diolah, 2018 
Tabel 2. Distribusi Pasien LLA Berdasarkan Variabel Penelitian dan Status Survival

\begin{tabular}{|c|c|c|c|c|c|c|c|}
\hline \multirow{3}{*}{ Variabel Penelitian } & \multicolumn{4}{|c|}{ Status Survival } & \multirow{2}{*}{\multicolumn{2}{|c|}{ Total }} & \multirow{3}{*}{$\underset{(\log r a n k)}{p}$} \\
\hline & \multicolumn{2}{|c|}{ Event } & \multicolumn{2}{|c|}{ Sensor } & & & \\
\hline & $\bar{n}$ & $\%$ & $\mathrm{n}$ & $\%$ & $\mathbf{n}$ & $\%$ & \\
\hline \multicolumn{8}{|l|}{ Umur (tahun) } \\
\hline$<1$ dan $>10$ & 17 & 65.4 & 9 & 34.6 & 26 & 100 & \\
\hline $1-10$ & 52 & 62,7 & 31 & 37,3 & 83 & 100 & 0,190 \\
\hline \multicolumn{8}{|l|}{ Jenis Kelamin } \\
\hline $\begin{array}{l}\text { Laki-laki } \\
\text { Perempuan }\end{array}$ & $\begin{array}{l}40 \\
29\end{array}$ & $\begin{array}{l}60,6 \\
67,4\end{array}$ & $\begin{array}{l}26 \\
14\end{array}$ & $\begin{array}{l}39,4 \\
32,6\end{array}$ & $\begin{array}{l}70 \\
39\end{array}$ & $\begin{array}{l}100 \\
100\end{array}$ & 0,163 \\
\hline \multicolumn{8}{|l|}{ Status Gizi } \\
\hline $\begin{array}{l}\text { Abnormal } \\
\text { Normal }\end{array}$ & $\begin{array}{l}50 \\
19\end{array}$ & $\begin{array}{l}71,4 \\
48,7\end{array}$ & $\begin{array}{l}20 \\
20\end{array}$ & $\begin{array}{l}28,6 \\
51,3\end{array}$ & $\begin{array}{l}70 \\
39\end{array}$ & $\begin{array}{l}100 \\
100\end{array}$ & 0,028 \\
\hline
\end{tabular}

Sumber: Data Sekunder yang Telah Diolah, 2018.

Tabel 3. Hasil Analisis Cox Regression Model Interaksi

\begin{tabular}{clccccccc}
\hline \multirow{2}{*}{ Step } & \multicolumn{1}{c}{ Variabel } & \multirow{2}{*}{ B } & SE & Wald & \multirow{2}{*}{ Sig. } & \multirow{2}{*}{ HR } & \multicolumn{2}{c}{ 95\% CI for HR } \\
\cline { 8 - 10 } & & & & & Lower & Upper \\
\hline 1 & Status Gizi & 0,613 & 0,332 & 3,401 & 0,065 & 1,846 & 0,962 & 3,542 \\
& Umur*Status Gizi & 0,268 & 0,335 & 0,640 & 0,424 & 1,307 & 0,678 & 2,521 \\
& Jenis Kelamin*Status Gizi & $-0,183$ & 0,293 & 0,391 & 0,532 & 0,833 & 0,469 & 1,478 \\
2 & Status Gizi & 0,498 & 0,281 & 3,139 & 0,076 & 1,646 & 0,948 & 2,857 \\
& Umur*Status Gizi & 0,255 & 0,334 & 0,581 & 0,446 & 1,290 & 0,670 & 2,485 \\
3 & Status Gizi & 0,553 & 0,270 & 4,197 & 0,040 & 1,739 & 1,024 & 2,952 \\
\hline
\end{tabular}

Sumber: Data Sekunder yang Telah Diolah, 2018.

\section{PEMBAHASAN}

Penelitian ini menunjukkan bahwa proporsi kesintasan 4 tahun (48 bulan) pasien LLA pada anak di RSUP Dr. Wahidin Sudirohusodo Makassar sebesar 26\%. Angka kesintasan pada penelitian ini lebih rendah jika dibandingkan dengan hasil penelitian yang diperoleh oleh Wijayanti \& Supriadi (2017) di Yogyakarta, dimana angka kesintasan anak dengan LLA sebesar 56,1\%. Selain itu, ada perbedaan yang cukup signifikan antara angka kesintasan pasien LLA pada penelitian ini dengan penelitian yang dilakukan oleh Erdmann et al. (2014) di Jerman dan Lins et al. (2016) di Brazil. Angka kesintasan dari kedua penelitian tersebut lebih dari $75 \%$. Hal ini menunjukkan angka kesintasan pasien LLA di negara berkembang masih sangat rendah jika dibandingkan dengan negara maju. Perbedaan angka kesintasan pasien LLA ini kemungkinan karena perbedaan kondisi pasien seperti faktor individu, faktor kanker, dan faktor penanganan pasien leukemia di masing-masing lokasi penelitian, serta perbedaan lama waktu follow-up. 
Rendahnya proporsi ketahanan

hidup pasien LLA pada anak yang didiagnosis di RSUP Dr. Wahidin Sudirohusodo Makassar disebabkan oleh beberapa faktor, seperti banyak pasien yang pulang atas permintaan sendiri (pulang paksa) dalam kondisi yang memburuk sehingga banyak pasien LLA yang meninggal karena tidak melakukan pengobatan. Selain itu, banyak juga pasien yang menolak kemoterapi dan tidak melanjutkan pengobatan karena efek samping yang ditimbulkan oleh kombinasi obat-obat sitostika pada pengobatan kemoterapi.

Penelitian ini menunjukkan hasil bahwa tidak ada hubungan antara umur dan kesintasan pasien LLA pada anak. Proporsi event pada pasien LLA yang berumur $<1$ dan $>10$ tahun maupun umur 1-10 tahun tidak terlalu signifikan perbedaannya yaitu $65,4 \%$ dan $62,7 \%$. Hasil penelitian ini sejalan dengan penelitian yang dilakukan oleh Kulkarni et al (2009) di India dan Erdmann et al. (2014) di Jerman yang menyimpulkan bahwa umur tidak berhubungan dengan probabilitas kesintasan penderita LLA. Namun, hasil yang berbeda ditemukan oleh Sousa et al. (2015), Hossain et al. (2014), Ma et al. (2014), dan Permatasari et al. (2009) yakni bahwa umur berpengaruh secara signifikan terhadap probabilitas kesintasan anak dengan LLA. Anak yang berumur kurang dari 1 tahun memiliki angka kesintasan terendah. Perbedaan hasil penelitian ini bisa disebabkan karena perbedaan pengkategorian umur di antara penelitian tersebut.

Penelitian ini juga menunjukkan tidak ada hubungan antara jenis kelamin dengan kesintasan pasien LLA pada anak. Proporsi event pada pasien LLA yang berjenis kelamin laki-laki maupun perempuan tidak terlalu signifikan perbedaannya yaitu $60,6 \%$ dan $67,4 \%$. Hasil penelitian ini sejalan dengan penelitian yang dilakukan oleh Pui et al. (2004), Permatasari et al. (2009), Kulkarni et al. (2009) dan Halalsheh et al. (2011). Keempat penelitian menunjukkan bahwa tidak ada hubungan antara jenis kelamin dengan kesintasan pasien LLA. Baik pasien LLA yang berjenis kelamin lakilaki maupun perempuan lebih banyak yang meninggal daripada yang masih bertahan hidup (survive). Namun, hasil yang berbeda dilaporkan oleh Simanjorang et al. (2013), Ma et al. (2014), dan Gupta et al. (2014) yang menemukan bahwa ada perbedaan angka ketahanan hidup pasien LLA yang signifikan berdasarkan jenis kelamin. Angka ketahanan hidup pasien yang berjenis kelamin perempuan lebih tinggi dibandingkan dengan pasien lakilaki. Laki-laki berisiko lebih besar mengalami kematian dibandingkan perempuan. Hasil penelitian ini juga tidak sejalan dengan teori yang menyatakan bahwa jenis kelamin laki-laki memiliki 
prognosis yang buruk dibandingkan jenis

kelamin perempuan (Permono, 2012).

Faktor prognosis yang berhubungan dengan ketahanan hidup pasien LLA pada penelitian ini adalah status gizi. Paling banyak pasien LLA dengan status gizi abnormal yang mengalami event $(71,4 \%)$. Proporsi ketahanan hidup pasien dengan gizi abnormal lebih rendah dibandingkan dengan pasien LLA dengan gizi normal. Hasil penelitian ini sejalan dengan penelitian Gelelete et al. (2011), Orgel et al. (2014) dan Eissa et al. (2017) yang menyimpulkan bahwa obesitas mempengaruhi prognosis pasien LLA pada anak. Pasien LLA yang mengalami obesitas memiliki ketahanan hidup yang lebih buruk dibandingkan pasien nonobesitas. Salah satu faktor risiko terjadinya leukemia adalah karena adanya mutasi gen. Obesitas dapat mempercepat laju mutasi sel atau mengganggu mekanisme seluler perbaikan DNA yang mengakibatkan peristiwa mutasi (Lichtman, 2010). Oleh karena itu, pasien LLA dengan gizi abnormal cenderung memiliki prognosis yang buruk.

\section{KESIMPULAN DAN SARAN}

Proporsi ketahanan hidup 48 bulan pasien LLA pada anak di RSUP Dr. Wahidin Sudirohusodo Makassar sebesar $26 \%$. Faktor prognosis yang berhubungan secara signifikan dengan kesintasan pasien LLA adalah status gizi. Stratifikasi pengobatan leukemia berdasarkan faktor prognosis yang berhubungan dengan ketahanan hidup pasien LLA perlu dilakukan untuk meningkatkan keberhasilan pengobatan.

\section{DAFTAR PUSTAKA}

Eissa., et al. (2017). The effect of body mass index at diagnosis on clinical outcome in children with newly diagnosed acute lymphoblastic leukemia. Blood Cancer Journal, 7(e531):1-7.

Erdmann, F., Kaatsch, P., Zeeb, H., Roman, E., Lightfoot, T. \& Schüz, J. (2014). Survival from childhood acute lymphoblastic leukaemia in West Germany: Does sociodemographic background matter? European journal of cancer, 50(7): 1345-1353.

Gelelete., et al. (2011). Overweight as a prognostic factor in children with acute lymphoblastic leukemia. Obesity, 19(9): 1908-1911.

Gupta, S., Sutradhar, R., Guttmann, A., Sung, L. \& Pole, J. D. (2014). Socioeconomic status and event free survival in pediatric acute lymphoblastic leukemia: A population-based cohort study. Leukemia research, 38:1407-1412.

Halalsheh, H., Abuirmeileh, N., Rihani, R., Bazze, F., Zaru, L. \& Madanat, F. (2011). Outcome of Childhood Acute Lymphoblastic Leukemia in Jordan. Pediatr Blood Cancer, 57:385-391.

Hoed., et al. (2015). The negative impact of being underweight and weight loss on survival of children with acute lymphoblastic leukemia. Haematologica, 100(1): 62-69.

Hossain, M. J., Xie, L. \& McCahan, S. M. (2014). Characterization of Pediatric Acute Lymphoblastic Leukemia Survival Patterns by Age at Diagnosis. Journal of Cancer Epidemiology, 865979:1-9. 
Kemenkes RI. (2016). Kendalikan Kanker pada Anak. Jakarta: Kementerian Kesehatan Republik Indonesia.

Kulkarni, K. P., Marwaha, R. K., Trehan, A. \& Bansal, D. (2009). Survival Outcome in Childhood ALL: Experience From a Tertiary Care Centre in North India. Pediatr Blood Cancer, 53:168-173.

Lichtman, M. A. (2010). Obesity and the risk for a hematological malignancy: leukemia, lymphoma, or myeloma. The oncologist, 15:1083-1101.

Lins et al. (2017). Incidence and survival of childhood leukemia in Recife, Brazil: A population based analysis. Pediatric blood \& cancer, 64(8):1-6.

LLS. (2018). Fact 2016-2017. New York: Leukemia \& Lymphoma Society.

Ma, H., Sun, H. \& Sun, X. (2014). Survival improvement by decade of patients aged $0-14$ years with acute lymphoblastic leukemia: a SEER analysis. Scientific Report, 4(4227):1-8.

Orgel et al. (2014). Obesity is associated with residual leukemia following induction therapy for childhood Bprecursor acute lymphoblastic leukemia. Blood, 124(26):39323938.

Permatasari, E., Windiastuti, E. \& Satari, H. I. (2009). Survival and prognostic factors of childhood acute lymphoblastic leukemia. Paediatrica Indonesiana, 49(6):365-371.

Permono, B. \& Ugrasena, I. (2012). Buku Ajar Hematologi-Onkologi Anak. Jakarta: Ikatan Dokter Anak Indonesia.
Pui et al. (2004). Improved outcome for children with acute lymphoblastic leukemia: results of Total Therapy Study XIIIB at St Jude Children's Research Hospital. Blood, 104(9):2690-2696.

Rekam Medik RSUP Dr. Wahidin Sudirohusodo. (2018). Data Pasien Rawat Inap Leukemia Akut Tahun 2012-2017. Makassar: RSUP Dr. Wahidin Sudirohusodo.

Simanjorang, C., Kodim, N. \& Tehuteru, E. (2013). Perbedaan Kesintasan 5 Tahun Pasien Leukemia Limfoblastik Akut dan Leukemia Mieloblastik Akut pada Anak di Rumah Sakit Kanker "Dharmais", Jakarta, 1997-2008. Indonesian Journal of Cancer, 7(1):15-21.

Sousa, D. W. L. D., Ferreira, F. V. D. A., Félix, F. H. C. \& Lopes, M. V. D. O. (2015). Acute lymphoblastic leukemia in children and adolescents: prognostic factors and analysis of survival. Rev Bras Hematol Hemoter, 37(4):223-229.

Wijayanti, L. P. \& Supriyadi, E. (2017). Faktor Prognosis dan Kesintasan Pasien Leukemia Limfoblastik Akut Anak di RSUP Dr. Sardjito, Yogyakarta, 2010-2015. Indonesian Journal of Cancer, 11(4):145-150.

Wirawan et al. (2003). Diagnostik Leukemia Limfositik Akut: Morfologi, Imunofenotip, Sitogenetik, dan Molekuler. Majalah Kedokteran Indonesia, 53(1). 